\title{
Causal Model of Variables Affecting the Creativity of Undergraduate Students
}

\author{
Banjob Boonchan1,2, Phadungchai Pupat ${ }^{3}$, Boonchan Seesan ${ }^{3}$ \\ ${ }^{1}$ Curriculum Research and Development, Faculty of Industrial Education, King Mongkut's Institute of Technology, Ladkrabang, \\ Thailand \\ ${ }^{2}$ Department of Educational Administration, Nakhon Ratchasima Rajabhat University, Nakhon Ratchasima, Thailand \\ ${ }^{3}$ Faculty of Industrial Education, King Mongkut's Institute of Technology, Ladkrabang, Thailand \\ Email: banjobbun@yahoo.com
}

How to cite this paper: Boonchan, B., Pupat, P., \& Seesan, B. (2017). Causal Model of Variables Affecting the Creativity of Undergraduate Students. Creative Education, 8, 279-293.

https://doi.org/10.4236/ce.2017.82022

Received: November 20, 2016

Accepted: February 25, 2017

Published: February 28, 2017

Copyright (C) 2017 by authors and Scientific Research Publishing Inc. This work is licensed under the Creative Commons Attribution International License (CC BY 4.0).

http://creativecommons.org/licenses/by/4.0/

c) (i) Open Access

\begin{abstract}
This research aims to select variables affecting the creativity of undergraduate students and to develop a causal model from the results. A total of 760 students participated in this study. The instruments used were the Torrance Tests of visual and written language and a questionnaire about the variables that influence creativity. Also a confirmatory factor analysis (CFA), mean and standard deviations, and a path analysis with the LISREL version 8.8 and SPSS program were used. The results show that administration, teaching, instructional climate, motivation, and personality are the variables that affect the creativity of the undergraduate students. The results from the CFA show an acceptable goodness-of-fit. The means of creativity and variables affecting creativity of the undergraduate students were at a medium and high level (between 2.98 to 3.05 and between 3.94 to 4.13 ), respectively. The goodnessof-fit of the causal model of the variables affecting the creativity of the undergraduate students was developed on the basis of the empirical data as well. The statistical results obtained were $\chi^{2}=125.28, \mathrm{df}=104$, $\mathrm{p}$-value $=0.07622$, GFI $=0.98$, AGFI $=0.97$ and RMSEA $=0.016$, all of which are based on specified criteria.
\end{abstract}

\section{Keywords}

Causal Model, Creativity, Confirmatory Factor Analysis, Goodness of Fit

\section{Introduction}

In the 21st century, students should develop three core skills including learning skills, life skills, and information and technology skills. These skills are known as the 21st century skills. Learning skills consist of critical thinking, communication, teamwork, and create innovation, while life skills include ones' life goals 
acknowledgement, motivation, a good planner, a right decision maker, responsibility for the results of decision making, work achievement expectation, a selfevaluation realization, and flexibility. Nonetheless, the information and technology skills including the perceiving of up to date information, and being smart to the usage of new information technology is also very important (Trilling \& Fadel, 2009).

Regarding the drastic changes in social, economics, politic, and the rapid growth of technology and communication as well as the life in the digital age occur all the time, students should have skills which are necessary to survive in the 21st century. Those skills relate to the creativity and the innovation skills. Students should have a capability to express their creativity, construct knowledge and develop the innovation using technology both in the process and product. Students should also apply their existed knowledge to generate new ideas, new products or a new process in order to create a prototype which symbolizes self or group identity. In addition, students should use the model and simulations to investigate the system and the complex problems in order to find out the trends and forecast the possibilities.

Such changes caused the flow of information, the domination of science and technology as well as the conflict of a variety of prosperity. These changes call for the creation of a new learning method and concepts both in the institutions and entrepreneurships. The potentiality of concepts with the five mentality aspects is an ultimate power of the next era. Those mentality aspects include the dexterity, synthesis, creativity, respect, and ethic (Gardner, 2007). Education must be able to prepare people to live in the future world effectively. Creative thinking is seeking for new ideas and answers relevant to the interests. Gardner also identifies that creative thinking is one of the minds that need to be cultivated for the future.

According to Torrance (1979) and Torrance \& Ball (1984), if any country is capable to seek out, develop, and extract out the potentiality of creativity of its nation to maximize the usefulness as much as it could, the nation would have more opportunity to be developed for prosperity. The potentiality of an educational system to promote innovation and creativity will be the indicators to measure the successfulness of the economics in the 21st century. An educational system must enable the learners to gather ideas in order to develop the original ideas or being a foundation idea of creativity (Patarawad, 2015).

The curriculum aims at promoting the students' creativity and having thinking skills. Thus, it is necessary to design the learning and teaching activities which enable the students to have more opportunity to think creatively and harmonize with the dynamic global context (Panich, 2013).

The development of thought is one of the approaches that will improve the quality of the learners. Practicing thinking skills and thinking processes are of significant factors to develop the learners' intelligence (Sindhvananda, 2013). The educators are increasingly given an importance to thinking due to the fact that they believe thinking can be developed and trained through the external en- 
vironment. The educational process of each country has determined the development and promotion of thinking in their National Education Act's purposes. Creativity can be promoted and developed both directly and indirectly, but it cannot be forced to occur (Roger, 1998). Everyone has their creativity intrinsically which can be developed both in children and adults. Creativity is a brain's competency to think broadly with multi-direction as follows: 1) originality, 2) frequency, 3) flexibility, and 4) elaboration (Guildford, 1991). There are several factors which might be the main reason for the development of learners' creativity such as the administration of the executive managements, the instructors' instructions, the institutions' climate, the instructors' motivations, the learners' personality, and etc. (Boonchan, Pupat, \& Seesan, 2015).

Nakhon Ratchasima Rajabhat University has six faculties (colleges) comprising the Faculty of Education, Faculty of Humanities and Social Sciences, Faculty of Industrial Technology, and the Faculty of Health Sciences. The campus population totals 20,615 students aged between 18 - 25 years. The Faculty of Education students are required to study 5 years unlike the other colleges' standard 4-year programs.

Because of the above mentioned rational, the researcher under the control of Nakhon Ratchasima Rajabhat University realizes the importance of creativity, and students' creativity promotion. Thus, the researcher has studied the causal model of the variables that influence the creativity of undergraduate students at Nakhon Ratchasima Rajabhat University. The model being suggested used four measurable aspects of creativity: originality, fluency, flexibility, and elaboration. In addition, administration, teaching, motivation, personality, and instructional climate variables contribute to undergraduate students' creativity. On the other hand, the results obtained in this study intend to draw up a plan which will develop the creativity of the undergraduate students by considering the variables affected and which may also be used as information to create innovation or model that encourage creativity.

\section{Literature Review}

\subsection{Factors Affecting the Creativity}

\subsubsection{Administration}

Administration is backbone of an organization. Thus an effective administration would run organization professionally and smoothly. Administration has always been at the heart of organization. The main responsibility of an administrator is to ensure the efficient performance in an organization. They act as a connecting link between the senior management and the employees. They provide motivation to the work force and make them realize the goals of the organization (Mishra, Dhar, \& Dhar, 1999). The first priority of leadership is to engage the right people, at the right times, to the right degree in creative work. That engagement starts when the leader recasts the role of employees. Rather than simply roll up their sleeves and execute top-down strategy, employees must contribute imagination (Amabile \& Khaire, 2008). According to 
Dimock (1986), creativity is perhaps the most important concept in public administration. Creativity is one of the hallmarks of leadership and is a central component in the science and, most particularly, the art of public administration. Managers can influence creativity in workers by instilling strong values, beliefs and assumptions that encourage creativity. Administration is another variable influencing the creativity of undergraduate students. This is probably due to the teachers believing that the administration encourages, supports and facilitates the directing of all activities of the university by the university executive committee. The focus group participants agreed that the composition of the three components is policy, mission, and identity with the administration contributing to the creative development of students.

\subsubsection{Personality}

Creative individuals are remarkable for their ability to adapt to almost any situation and to do with whatever is at hand to reach their goals (Csikszentmihalyi, 2011). Creative people tend to be both extroverted and introverted. In fact, in psychological research, extroversion and introversion are considered the most stable personality traits that differentiate people from each other and that can be reliably measured. Creative individuals, on the other hand, seem to exhibit both traits simultaneously (Nelson, Wood, \& Gabris, 2011). According to Stacey (1996), bureaucratic organizations with high levels of centralization are difficult to move in a creative direction because they have restricted information flow and few connections between individuals. The dominant system in a bureaucracy consists of routines, habits, and highly defined procedures. Rich information flow, many interconnections, and diversity of behaviours and perspectives provide the raw materials for new ideas. According to the research studies and examination of the literature, it was determined that there were three key manifest variables related to creativity, which is how students perceived themselves, both physically and mentally. Many scholars have studied these manifest variables effects on personality from which the researchers have synthesized the research to include freedom, self-trust and self-esteem in this study.

\subsubsection{Motivation}

There is now a large body of research evidence demonstrating some surprising findings about creativity. When people are focused on extrinsic motivationsi.e. rewards and punishments-their creativity suffers. But when they are driven by intrinsic motivations-e.g. interest, meaning, purpose, learning, freedomtheir creative performance soars (Basadur, 1992). As pointed out by Smith (1998), intrinsic motivation is difficult to identify because it is an internal, non-conscious process. According to the research studies and examination of the literature, it was determined that there were three key variables related to creativity. Motivation is demand, dynamic pressure or the desire to struggle in order to achieve its objectives, which may be caused naturally or by learning it, which has the researchers have synthesized the research to include needs, drive and satisfaction in this study. 


\subsubsection{Teaching}

Children can be taught creativity and that it can be done in a variety of ways. Coaching/mentoring can help encourage and develop creative thinking and problem-solving through reflection and discussion with an external person (Deans, Oakley, James, \& Wrigley, 2006). Jeffrey and Craft (2004) discussed the distinction between teaching creatively and teaching for creativity in its characterization of creative teaching. The former is defined as using imaginative approaches to make learning more interesting and effective. The latter is defined as forms of teaching that are intended to develop young people's own creative thinking or behaviour. Teaching and faculty instructional activities influence creativity of undergraduate students. According to the research studies and examination of the literature, it was determined that there were four key manifest variants or observable variables related to creativity. Many scholars have studied these manifest variants or observable variables effects on teaching from which the researchers have synthesized the research to include objectives, activity, content, and evaluation in this study.

\subsubsection{Instructional Climate}

A climate can be seen as various aspects of the psychological atmosphere. The climate often conveys expectations about which behaviors and attitudes that are acceptable (Amabile, 1998). Many components of a creative climate have been proposed during the years. Some examples are the degree of individual freedom, psychological safety, support and positive relationships among team members, vision provided by supervisors, creative encouragement, mission clarity, available resources, and even joy (Denti, 2011). However, Thammanit and Bussracumpakorn (2007) studied creativity of Thai adolescents between 15 - 18 years of age and stated in their key findings that "Thai adolescents cannot interpret information, generate ideas and develop creative ability in an effective way". This is consistent with Baczek (2013) that indicated that "Krengjai", one of the Thai values that encourage conflict avoidance, was indicated as one of the biggest barriers to creativity. According to the research studies and examination of the literature, it was determined that there were three key manifest variables related to creativity. Many scholars have studied these manifest variables effects on instructional climate which is the student's perception concerning the learning environment, from which the researchers have synthesized the research to include support, acceptance, and participation in this study.

\subsection{Creativity}

Creativity is a difficult idea to define with one being able to find a number of definitions that describe it. Gibson (2005) considered creativity as individuality. Creativity however involves mostly two particular areas which are skills and personal characteristics. Creativity is often seen as a characteristic that a person possesses, a product or outcome that is regarded as original, and a process by which an unusual, novel or suitable outcome or solution is obtained. Amabile (1998) indicated that complex and challenging jobs that enable workers to de- 
cide how to carry out tasks are more likely to encourage intrinsic motivation that, in turn, increases creativity. Amabile's model of organizational creativity is one of the most widely cited in psychological studies of organizations (Heerwagen, 2002). Although not explicitly stated, the assumption behind the model is that creativity and innovation are important for all organizations and jobs. Rawlinson (2006) has stated that there are over 200 techniques used for the fostering of the creative potentials of a person. Some of these techniques are attribute listing, mind-mapping, check lists, forced relationships, $5 \mathrm{~W}$ 's and $\mathrm{H}$, lateral thinking and PO, and metaphorical thinking. The focus of this study was therefore to measure the creativity traits of the subjects in term of fluency, elaboration, flexibility and originality. According to the research studies and examination of the literature, it was determined that there were four key manifest variables related to creativity. Many scholars have studied these manifest variables effects on creativity from which the researchers have synthesized the research to include originality, fluency, flexibility and elaboration tasks in this study (Table 1).

\section{Methodology}

The study uses qualitative research in the first phase for investigating the variables affecting creativity from the expert discussions and quantitative research in the second phase for developing a causal model of the variables affecting the creativity.

Table 1. The latent and observed variables affecting the creativity of undergraduate students and theorists.

\begin{tabular}{|c|c|c|}
\hline Latent variables & Observed variables & Theorists/Researchers \\
\hline $\begin{array}{l}\text { Administration } \\
\text { (Admin) }\end{array}$ & $\begin{array}{l}\text { Policy (Pol) } \\
\text { Mission (Mis) } \\
\text { Identity (Ide) }\end{array}$ & $\begin{array}{l}\text { Dimock (1986), Amabile \& Khaire (2008), } \\
\text { Mishra, Dhar, \& Dhar (1999) }\end{array}$ \\
\hline Teaching (Teach) & $\begin{array}{c}\text { Objective (Obj) } \\
\text { Content (Con) } \\
\text { Activity (Act) } \\
\text { Evaluation (Eva) }\end{array}$ & $\begin{array}{l}\text { Jeffrey \& Craft (2004), Deans, Oakley, James, \& } \\
\text { Wrigley (2006) }\end{array}$ \\
\hline $\begin{array}{l}\text { Instructional } \\
\text { climate } \\
\text { (Clima) }\end{array}$ & $\begin{array}{c}\text { Support (Sup) } \\
\text { Accept (Acc) } \\
\text { Participation (Par) }\end{array}$ & $\begin{array}{l}\text { Amabile (1998), Thammanit \& Bussracumpakorn } \\
\text { (2007), Denti (2011), However \& Baczek (2013) }\end{array}$ \\
\hline Motivation (Motiv) & $\begin{array}{l}\text { Need (Nee) } \\
\text { Drive (Dri) } \\
\text { Satisfaction (Sat) }\end{array}$ & Basadur (1992), Smith (1998) \\
\hline Personality (Perso) & $\begin{array}{l}\text { Freedom (Fre) } \\
\text { Self-trust (Str) } \\
\text { Self-esteem (Ses) }\end{array}$ & $\begin{array}{l}\text { Stacey (1996), Csikszentmihalyi (2011), Nelson, } \\
\text { Wood, \& Gabris (2011) }\end{array}$ \\
\hline Creativity (Creat) & $\begin{array}{l}\text { Originality (Ori) } \\
\text { Fluency (Flu) } \\
\text { Flexibility (Fle) } \\
\text { Elaboration (Ela) }\end{array}$ & $\begin{array}{c}\text { Amabile (1998), Heerwagen (2002), Gibson } \\
\text { (2005), Rawlinson (2006) }\end{array}$ \\
\hline
\end{tabular}




\subsection{Participants}

\subsubsection{Phase 1}

In the first phase, nine experts from both inside and outside Nakhon Ratchasima Rajabhat University took part in a group discussion. All the experts were doctoral holders who were experts in their respective fields including: curriculum and instruction, curriculum research and development, educational measurement and evaluation, educational administration, or experienced in using creativity measurements. Additionally, all had been teaching for at least one year at tertiary level.

\subsubsection{Phase 2}

In the second phase, respondents included 760 undergraduate students, academic year 2015, selected by stratified random sampling by their faculty. The sample size of this study was determined by using a minimum set of samples. According to a preliminary agreement in analyzing structural equation modeling using LISREL (Lindeman, Merendaand, \& Gold, 1980), the ratio between a number of samples and a number of parameters, estimated or observed variables, is 20:1. To attribute a high correlation analysis as well as high statistics showing a pattern of relationships between variables, the researchers took into consideration the sample size adopting a ratio of 20 survey samples for a single variable used in the research (Tanaka \& Huba, 1987). As there were 38 variables for the study and if one uses a 20:1 ratio, 760 respondents constitute a highly accurate survey population.

\subsection{Instrumentation}

The instruments were a Torrance Tests of Creative Thinking (TTCT) with a reliability of 0.914 and a questionnaire on the variables affecting creativity, such as administration, teaching, instructional climate, motivation and personality, and the results obtained showed a reliability of $0.925,0.949,0.941,0.899$, and 0.925 , respectively. The Torrance Tests of Creativity Thinking (TTCT) is designed to identify and evaluate creative potential using two parts-a Verbal test and a Figural test. The tests are game-like to catch student's interests. The scoring of the tests is by hand and require careful attention to the manual for reliable results. However, streamlined guides are available and are helpful in developing greater familiarity with the test and its scoring procedures. The questionnaires which included 66 items, were collected from 760 respondents through a self-designed five-point Likert scale (ranging from Strongly Agree-5 to Strongly Disagree-1).

\subsection{Data Collection}

The researcher went into classes and measured the variables affecting the creativity with a questionnaire set and TTCT. Through a questionnaire with a five-point Likert scale, administration, teaching, instructional climate, motivation, and personality were measured. A TTCT provided a measure of students' general creative competence on originality, fluency, flexibility, and elaboration. 
Among the 760 respondents, there were 190 male (25\%) and 570 female (75\%). The respondents' age ranged from 18 to 23 years and the average age was 21 years. They were tested creativity then, answering the questionnaire on variables affecting creativity.

\subsection{Data Analysis}

As a primary data analysis method, Structural Equation Modeling (SEM) was used to find the relationship among latent constructs described in theoretical framework for creativity of undergraduate students. The SEM techniques is a confirmatory technique based on previous theory in contrast to exploratory factory analysis. All data were screened by the Statistical Package for the Social Sciences (SPSS) 16.00 version. The program LISREL 8.80 software version was used to estimate the framework (model) for research hypotheses.

\section{Results and Discussion}

The variables affecting the creativity of the undergraduate students consisted of administration, teaching, instructional climate, motivation, and personality. Administration is another variable influencing the creativity of undergraduate students obtained from group discussion. This is probably due to students thinking that the administration encourages, supports, facilitates, and directs all the activities of the university, under the direction of the university executive committee. A focus group of the participants agreed on composition of the three components of administration-policy, mission, and identity. Thus, the administration also contributes to the creative development of its students. Teaching in the form of instructional activities influences the creativity of undergraduate students (Craft, 2010). Motivation is demand, dynamic pressure or the desire to struggle in order to achieve its objectives, which has three main components, including needs, drive, and satisfaction, all of which influence the creativity of undergraduate students (Yokubon, 2012). Personality is perceived as whole, which has three main components, namely a sense of individual freedom, self-trust, and self-esteem influence the creativity of undergraduate students (Tawornwet, 2010). The instructional climate is the experience of learning on the campus, which has three main components, namely the support of faculty, acceptance of faculty, and the participation of students, all of which factors influence the creativity of undergraduate students (Kreasuwan, 2010).

Means and standard deviation of creativity and variables affecting the creativity of undergraduate students shown in Table 2.

Table 2 presents the statistical means for each of the components of the creativity of undergraduate students which were at a moderate level. Nakhon Ratchasima Rajabhat University is the institute for the local development of teacher training in the Northeast. The policy of creating educational opportunities and the mission of the university is to produce graduates and promote lifelong learning to ensure educated people and create a society of knowledge. As a result this policy creates educational opportunities for local residents, and produces the 
manpower to help meet both the local and the national demand.

Table 2 also presents the statistical means of the variables affecting the creativity of undergraduate students and shows that they were at a high level and personality was the highest mean. This is probably due to these variables being the components of creative development of students as Kawkangwan (2011) says these variables cannot be separated but they have a relationship which affects one other.

The results of the investigation into the goodness-of-fit of the causal model of the variables affecting the creativity of undergraduate students using structure equation modeling (SEM) are shown in Table 3.

Table 3 shows that the causal model of the variables affecting the creativity of undergraduate students which the researcher developed to fit the empirical data based on all the criteria (Schumacker \& Lomax, 2010; Hair et al., 2010).

Investigation of the goodness-of-fit of the causal model of the variables affecting the creativity of undergraduate students which was developed with the empirical data show a correlation with the empirical data as well (Figure 1). If

Table 2. Descriptive statistics for measurements of creativity and variables affecting the creativity.

\begin{tabular}{lccc}
\hline \multicolumn{1}{c}{ Variables } & Mean & Standard deviation & Descriptive rating \\
\hline 1. Creativity & & & \\
1.1 Originality & 2.97 & 1.37 & Moderate \\
1.2 Fluency & 2.99 & 1.37 & Moderate \\
1.3 Flexibility & 3.03 & 1.42 & Moderate \\
1.4 Elaboration & 3.05 & 1.41 & Moderate \\
Average & 3.01 & 1.19 & Moderate \\
2. Variables affecting the creativity & & & High \\
2.1 Administration & 3.94 & 0.50 & High \\
2.2 Teaching & 4.05 & 0.50 & High \\
2.3 Instructional climate & 4.12 & 0.55 & High \\
2.4 Motivation & 4.08 & 0.50 & High \\
2.5 Personality & 4.14 & 0.52 & High \\
$\quad$ Average & 4.07 & 0.45 & \\
\hline
\end{tabular}

Table 3. The goodness-of-fit index and the predictive correlation of causal model of variables affecting the creativity of undergraduate students.

\begin{tabular}{cccc}
\hline Goodness-of-fit index & Criteria & Statistics & Decision \\
$\chi^{2}$ & $p>0.05$ & 0.076 & Passed \\
$\chi^{2} / \mathrm{df}$ & $\leq 2.00$ & 1.20462 & Passed \\
GFI & $\geq 0.90$ & 0.98 & Passed \\
AGFI & $\geq 0.90$ & 0.97 & Passed \\
RMSEA & $<0.80$ & 0.016 & Passed \\
\hline
\end{tabular}




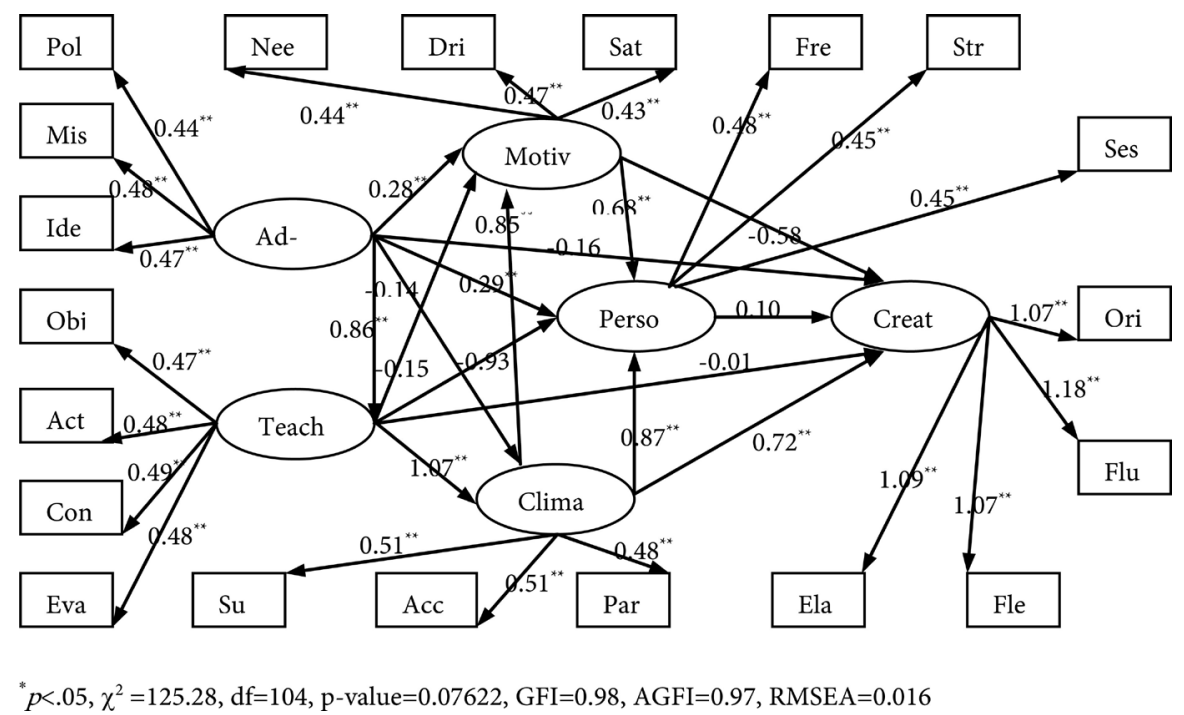

Figure 1. Magnitude of direct, indirect, and the total influences of variables.

we consider that $\chi^{2}=125.28, \mathrm{df}=104, \mathrm{p}$-value $=0.07622, \mathrm{GFI}=0.98, \mathrm{AGFI}=$ 0.97 and RMSEA $=0.016$ which is based on the specified criteria, we find that the paths are statistically significant.

The path from the administration to teaching factor has equal influence at 0.86 . This is probably due to the administrators who control the teaching quality of the lecturers by letting students evaluate their lecturers' teachings at the end of each semester. Students can evaluate their lecturers' teachings qualitatively and quantitatively without identifying themselves who are. The administrators can use the performance as appraisal results to set up or determine policy or plan for lecturers' development while the lecturers use those results for self-improvement.

The path from the administration to instructional climate factor has equal influence at 0.14 . This is probably due to the administrators who must facilitate or provide instructional resources appropriately to meet the students' needs and relevant to the nature of each program. For examples, the students who are programing in Computer, they must have adequate computers which are a vital instrument for their study in this program and it must meet all students' needs. Similarly, the students who are programing in Classical Thai Dance, they must also have adequate costumes, accessories, tapes, television, and songs for their rehearsals as well as a transportation vehicle in case of external performance in order to gain direct experience. Moreover, in a case of students who are programing in Evaluation and Measurement, they need to have different software for analyzing different types of data so that if the administrators could facilitate and provide the equipment or learning resources to meet the students' needs and necessary for each program, this would create good learning climates in the university. According to the university policy, it aims to develop the quality of education at all levels so that all students receive a high quality of education and obtain higher academic achievement. Besides, they can learn to study for themselves and live happily in society (Ebneroumi \& Rishehri, 2011). 
The path which is influenced by the various variables from administration to motivation is equal to 0.28 . This is probably due to management policies which have created incentives for students. By promoting and developing faculty for teachers and educational personnel, they can achieve professional standards of performance. This provides strategic and operational guidance for the quality and a high standard of education for teachers, faculty and staff (Vedenpää \& Lonka, 2014). This is probably due to the administrators set up plans or activity to promote students' motivations for learning by assigning the teachers and related staffs to invite well-known guest speakers whom the students are interested in to inspire them for learning on their professional and needs basis. This is a point to indicate the value and significance of education in applying the knowledge as a tool for the future career.

The path from the administration to personality factor has equal influence of 0.29. This is probably due to management policies to develop in students the creative personality by ongoing personality development activity and the continual promotion of virtue, ethics and citizenship in the education system by: a) creating a learning process for the students to cultivate moral values and pride in Thailand, a public minded philosophy of sufficient economy; b) integrating a variety of learning activities, for example, academic, life skills, art, music, culture, and religion; c) developing the learning process and providing practical activities to develop citizenship, cultivate discipline, strengthen unity, and adherence to the democratic regime with the King as head; and d) create a network of cooperation between families, religious, educational institutions, in cultivating and developing ethics for students at all levels and in types of education (Snape et al., 2014). The university' administrators must be a role model of having good personality, create a faithfulness and trustworthiness in administering the institution which can lead students to follow or imitate the behavior and want to develop their own personality appropriately with the context. Besides, the university' administrators must conduct students' personality development activity continuously in order that the students have good personality, being oneself, seeing one self's values, and accepting one self-knowledge and capabilities.

The path of motivation influences and personality factors is equal to 0.68 . This is probably due to motivation which is a powerful mechanism to stimulate the body to act in particular direction. It is a necessary condition for the improvement of behaviour, actions or activities of individuals by means of intentional behaviour to achieve their desired goals. There is correlation between the level of creativity and the predominant motivation in the activities of an individual (Mynbayeva, Vishnevskay, \& Sadvakassova, 2016). Regarding the motivation of an individual is an intrinsic power which drives an individual to behave on their desires basis. The behavior can be observed from an individual' personality thus, if an individual has whatever motivation, s/he will act out the behavior which can be obviously seen from his/her personality.

The path from the instructional climate to the motivation factor which has the influences of 0.85 . This is possibly due to the climate in the classroom that allows 
students to learn based on their interests and aptitudes. It can be seen that characteristics, beliefs values, philosophy, or the ideals of different teachers will influence and affect students differently. Kreasuwan (2010) studied the relationship between the incentives to work, the organization climate, and a case study of the organization of justice, and Ministry of Transport. The study found that the overall relationship of incentives to work and the organization climate, organizational climate and organization justice, and incentives to work and organization justices has a positive relationship with a statistical significance at 0.01 . It is because a good learning climate can promote motivation for learning. In the other hand, if the climate in the classroom is not good, it can lead the learners to have demotivation in learning, have negative attitude towards the teachers, and finally get bored to learning.

The path from teaching to the instructional climate factor has the influences of 1.07. This is probably because of the psychological processes that enhance the learning of students who are effectively promoted by teachers who help students to express themselves through appropriate behaviour. Teaching isn't merely transmitting knowledge to students; it's also about teaching students to approach learning in engaging and approaching unexpected ways (Drapeau, 2014). Thus, they can communicate their needs and feelings effectively. This will create a positive impact on the classroom climate. A good atmosphere in class facilitates and promotes effective learning and the development of the personality of students. The teaching behavior of the lecturers will always correlate with the learning climate most. This might be resulted from the designing of teaching and learning activities which are mostly made by the teachers. The good climate of teachings is such as assigning students to participate in the activities, accepting the knowledge and capability of an individual student, treating each student equally, being friendly with them, and accepting their comments, and etc. There are many different dimensions of creativity, both in inputs and outputs, and a key challenge for policymakers and educators is to understand for which inputs increasing their levels will lead to higher levels of creativity in the economy, and on how to create an enabling environment for the effective transfer of creative inputs - such as education - into creative outputs - such as new business formation. Further research should concentrate on other variables such as socioeconomic, nurturing, emotional quotient, reasoning ability, and achievement that influencing creativity of the students. In addition, data analysis, should be analyzed by Hierarchical Linear Modeling (HLM) which is a complex form of ordinary least square (OLS) regression that is used to analyze variance in the outcome variables when the predictor variables are at varying hierarchical levels. HLM accounts for the shared variance in hierarchically structured data. The techniques accurately estimates lower-level slopes and their implementation in estimating higher-level outcomes.

\section{Conclusion and Recommendation}

The variables affecting creativity consisted of teaching, motivation, personality, 
and atmosphere of learning and teaching. Hence, the end users of this research should be taken into consideration regarding these variables directly or indirectly influencing creativity of the students. To avoid the duplication of conducting activities as well as to high yield efficiency on budgeting, the cooperation within the faculty should be made.

According to the goodness-of-fit index of model, the alternative model was well harmonized to the empirical data. The executive committee of the university must understand about what are the motivations that can promote students' creativity. The students should be supported, assisted, and suggested to conduct activities relied on their interests. They should be admired their success regarding the creativity development.

\section{References}

Amabile, T. (1998). How to Kill Creativity. Harvard Business Review, 76, 76-87.

Amabile, T. M., \& Khaire, M. (2008). Creativity and the role of the leader. Harvard Business Review, 86, 100-109.

Baczek, K. (2013). Effective Leadership in Thailand: Exploratory Factor Analysis of Creativity, Need for Achievement, Emotional Intelligence, and Diversity. http://tinyurl.com/zk8smto

Basadur, M. (1992). Managing Creativity: A Japanese Model. Academy of Management Executive, 6, 29-41. https://doi.org/10.5465/ame.1992.4274394

Boonchan, B., Pupat, P., \& Seesan, B. (2015). Variables Affecting the Creativity of Undergraduate Students at Nakhon Ratchasima Rajabhat University. Creative Education, 6, 2241-2249. https://doi.org/10.4236/ce.2015.621231

Craft, A. (2010). Teaching for Possibility Thinking-What Is It and How Do We Do It? Learning Matters, 15, 19-23.

Csikszentmihalyi, M. (2011). The Creative Personality. https://www.psychologytoday.com/articles/.../the-creative-personality

Deans, F., Oakley, L., James, R., \& Wrigley, R. (2006). Coaching and Mentoring for Leadership Development in Civil Society. https://books.google.co.th/books?isbn=3954894904

Denti, L. (2011). Leadership and Innovation: How and When Do Leaders Influence Innovation in R\&D Teams? Gothenburg: University of Gothenburg Press.

Dimock, M. (1986). Creativity. Public Administration Review, 46, 3-7. https://doi.org/10.2307/975436

Drapeau, P. (2014). Sparking Student Creativity: Practical Ways to Promote Innovative Thinking and Problem Solving. North Garden, VA: ASCD.

Ebneroumi, S., \& Rishehri, A. P. (2011). Towards a Conceptual Framework for the Characteristics of a Creative School. Social and Behavioral Sciences, 15, 2253-2258. https://doi.org/10.1016/j.sbspro.2011.04.089

Gardner, H. (2007). Five Minds for the Future. Cambridge, MA: Harvard Business Review.

Gibson, H. (2005). What Creativity Isn't? The Presumptions of Instrumental and Individual Justifications for Creativity in Education. British Journal of Educational Studies, 53, 148-167. https://doi.org/10.1111/j.1467-8527.2005.00288.x

Guildford, J. P. (1991). Some Changes in the Structure of Intellect Model. Educational and Psychological Measurement, 48, 1-4. 
Hair, J. F, Black, W. C., Babin, B. J., \& Anderson, R. E. (2010). Multivariate Analysis. Upper Saddle River, NJ: Pearson Education International.

Heerwagen, J. H. (2002). Creativity-Chapter 15. http://tinyurl.com/7jf56gg

Jeffrey, B., \& Craft, A. (2004). Teaching Creatively and Teaching for Creativity: Distinctions and Relationships. Educational Studies, 30, 77-87. https://doi.org/10.1080/0305569032000159750

Kawkangwan, S. (2011). Theory of Personality Psychology. Bangkok: Community Doctor.

Kreasuwan, U. (2010). Relationship among Work Motivation, Organizational Climate and Organizational Justice: A Case Study Department of Rural Road (Head Quarter) Ministry of Transport. MS Thesis, Chonburi: Burapa University.

Lindeman, R. H., Merenda, P. F., \& Gold, R. Z. (1980). Introduction to Bivariate and Multivariate Analysis. Glenview, IL: Scott, Foresman and Company.

Mishra, P., Dhar, U., \& Dhar, S. (1999). Job Satisfaction as a Correlate of HRD Climate: An Empirical Study. Indian Journal of Training \& Development, 29, 5.

Mynbayeva, A., Vishnevskay, A., \& Sadvakassova, Z. (2016). Experimental Study of Developing Creativity of University Students. Social and Behavioral Sciences, 217, 407-413. https://doi.org/10.1016/j.sbspro.2016.02.113

Nelson, K. L., Wood, C. H., \& Gabris, G. T. (2011). Innovation Management in Local Government: An Empirical Analysis of Suburban Municipalities. International Journal of Organization Theory and Behavior, 14, 301-328.

Panich, W. (2013). Learning Path for Students in the 21st Century. Bangkok: Sodsri-Saridwong Foundation.

Patarawad, K. (2015). Local Education Reset for Society Equity. Bangkok: King Prajadhipok's Institute.

Rawlinson, J. G. (2006). Creative Thinking and Brainstorming. New Delhi: Jaico Publishing House.

Roger, C. R. (1998). Freedom to Learn for the 80s. New York, NY: Free Press.

Schumacker, R. E., \& Lomax, R. G. (2010). A Beginner's Guide to Structural Equation Modeling. New York, NY: Routledge.

Sindhvananda, S. (2013). Develop Thinking Skill. Bangkok: Leangsiang.

Smith, G. F. (1998). Idea-Generation Techniques: A Formulary of Active Ingredients. Journal of Creative Behavior, 32, 107-133. https://doi.org/10.1002/j.2162-6057.1998.tb00810.x

Snape, D. J., Davies, D., Collier, C., Howe, A., Digby, R., \& Hay, P. (2014). The Impact of Creative Learning Environments on Learners: A Systematic Literature Review. Improving School, 16, 21-31. https://doi.org/10.1177/1365480213478461

Stacey, R. D. (1996). Complexity and Creativity in Organizations. San Francisco, CA: Berrett-Koehler.

Tanaka, J. S., \& Huba, G. J. (1987). A Fit Index for Covariance Structure Models under Arbitrary GLS Estimation. British Journal of Mathematical and Statistical Psychology, 38, 197-201. https://doi.org/10.1111/j.2044-8317.1985.tb00834.x

Tawornwet, P. (2010). Healthy p Personality. Bangkok: Attention.

Thammanit, V., \& Bussracumpakorn, C. (2007). Creativity Problems of the Thai Adolescents: Body-Brain-Mind Approach. www.arch.kmutt.ac.th/index.php/about/files/.../handbook.pdf?ln

Torrance, E. P. (1979). The Search for Satori \& Creativity. Buffalo, NY: Creative Education Foundation. 
Torrance, E. P., \& Ball, O. E. (1984).Torrance Tests of Creative Thinking Streamlined (Revised) Manual, Figural A and B. Bensenville, IL: Scholastic Testing Service.

Trilling, B., \& Fadel, C. (2009). 21st Century Skills: Learning for Life in Our Times. San Francisco, CA: Jossey-Bass.

Vedenpää, I., \& Lonka, K. (2014). Teachers' and Teacher Students' Conceptions of Learning and Creativity. Creative Education, 5, 1821-1833.

https://doi.org/10.4236/ce.2014.520203

Yokubon, N. (2012). Factors Affecting the Achievement of Science, Grade 6 Students at Demonstration Schools under the Commission of Higher Education, Ministry of Education. Journal of Education and Social Development, 8, 85-102.

Submit or recommend next manuscript to SCIRP and we will provide best service for you:

Accepting pre-submission inquiries through Email, Facebook, LinkedIn, Twitter, etc. A wide selection of journals (inclusive of 9 subjects, more than 200 journals)

Providing 24-hour high-quality service

User-friendly online submission system

Fair and swift peer-review system

Efficient typesetting and proofreading procedure

Display of the result of downloads and visits, as well as the number of cited articles Maximum dissemination of your research work

Submit your manuscript at: http://papersubmission.scirp.org/

Or contact ce@scirp.org 